ENVIRONMENTAL RESTORATION PROGRAM

\section{Environmental Restoration Risk-based Prioritization Work Package Planning and Risk Ranking Methodology}

June 1995 Revision 


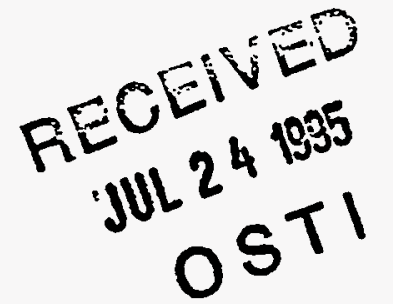

ENVIRONMENTAL RESTORATION PROGRAM

\section{Environmental Restoration Risk-based Prioritization Work Package Planning and Risk Ranking Methodology} June 1995 Revision 
This report has been reproduced directly from the best available copy.

Available to DOE and DOE contractors from the Office of Scientific and Technical Information, P.O. Box 62, Oak Ridge, TN 37831; prices available from 615-576-8401, (fax 615-576-2865)

Available to the public from the National Technical Information Service, U.S. Department of Commerce, 5285 Port Royal Rd., Springfield, VA 22161. 


\section{Environmental Restoration Risk-based Prioritization Work Package Planning and Risk Ranking Methodology}

June 1995 Revision

\author{
J. L. Dail \\ L. D. Nanstad \\ R. K. White
}

Date Issued-June 1995

Prepared by the

Risk Assessment Program

Lockheed Martin Energy Systems, Inc.

Prepared for the

U.S. Department of Energy

Office of Environmental Management under budget and reporting code EW 20

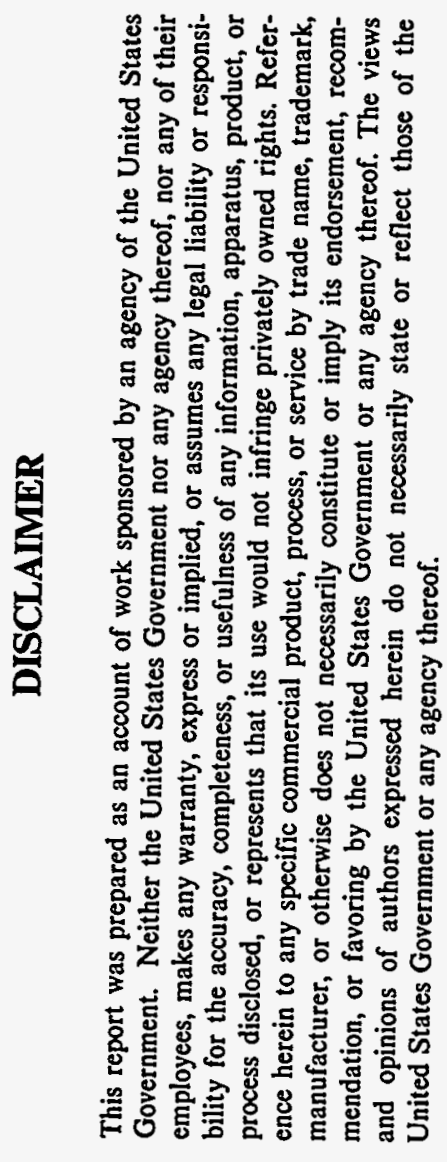

\section{LOCKHEED MARTIN ENERGY SYSTEMS, INC.}

managing the

Environmental Restoration and Waste Management Programs at

Oak Ridge K-25 Site Paducah Gaseous Diffusion Plant

Oak Ridge Y-12 Plant Portsmouth Gaseous Diffusion Plant

Oak Ridge National Laboratory

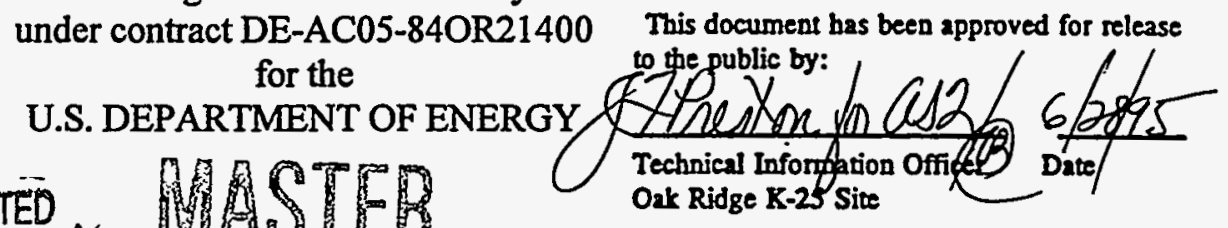




\section{DISCLAIMER}

Portions of this document may be illegible in electronic image products. Images are produced from the best available original document. 


\section{PREFACE}

This Environmental Restoration Risk-based Prioritization Methodology (ES/ER/TM-112/R2) was prepared for the Environmental Restoration (ER) Program in support of the increased rigor and formality of work planning initiated in the conduct of operations within ER. This work was performed under Work Breakdown Structure 1.4.12.2.3.04.07.01(Activity Data Sheet 8304, "Risk Assessment Review Planning \& Coordination"). The methodology discussed in this report was developed to evaluate and rank ER work packages on the basis of overall value (e.g., risk reduction, stakeholder confidence) to ER. This document presents the technical basis for the decision support tools and prioritization process. The methodology has been endorsed by the U.S. Department of Energy-Oak Ridge Operations (DOE-ORO) and its application facilitates an appropriate integration of ER projects into the DOE-ORO Office of Environmental Restoration baseline. 



\section{CONTENTS}

FIGURES $\ldots \ldots \ldots \ldots \ldots \ldots \ldots \ldots \ldots \ldots \ldots \ldots \ldots \ldots \ldots \ldots \ldots \ldots \ldots \ldots \ldots \ldots \ldots$

TABLES $\ldots \ldots \ldots \ldots \ldots \ldots \ldots \ldots \ldots \ldots \ldots \ldots \ldots \ldots \ldots \ldots \ldots \ldots \ldots \ldots \ldots \ldots \ldots \ldots$

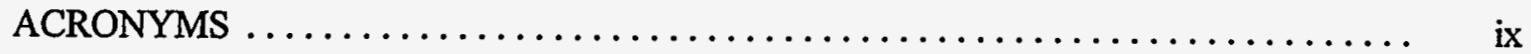

EXECUTIVE SUMMARY $\ldots \ldots \ldots \ldots \ldots \ldots \ldots \ldots \ldots \ldots \ldots \ldots \ldots \ldots \ldots \ldots \ldots \ldots \ldots \ldots$

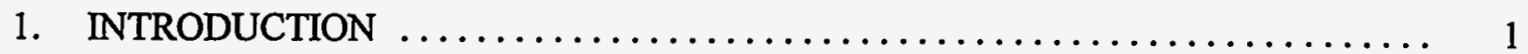

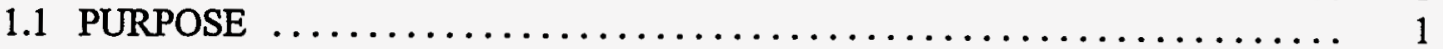

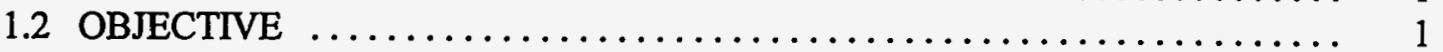

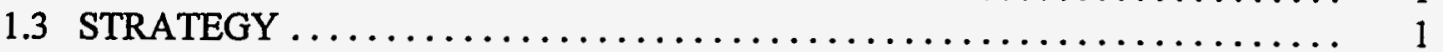

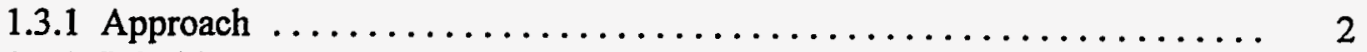

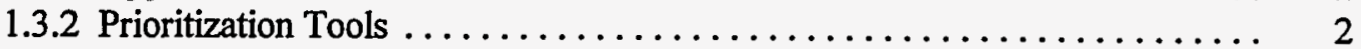

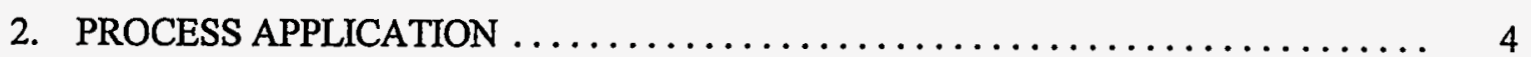

2.1 PROCESS APPLICATION STEPS $\ldots \ldots \ldots \ldots \ldots \ldots \ldots \ldots \ldots \ldots \ldots \ldots, 4$

2.1.1 Identification of Candidate Work Packages $\ldots \ldots \ldots \ldots \ldots \ldots \ldots \ldots$

2.1.2 Evaluation of Candidate Work Package ................... 4

2.1.3 Development of Risk-based Priority List ................. 4

2.1.4 Development of Fiscal Resource Requests ................ 4

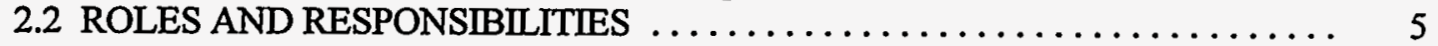

2.2.1 Site-level ER Program/project Managers and Technical Experts ....... 5

2.2.2 ORNL Center for Risk Management $\ldots \ldots \ldots \ldots \ldots \ldots \ldots \ldots \ldots \ldots$

2.2.3 ER Business Operations .......................... 5

2.2.4 Upper-level MMES and DOE ER Managers ............... 5

2.2.5 Representatives from Appropriate Federal and State Regulatory Agencies ... 6

2.3 CONDUCT OF ER PRIORITIZATION BOARD SESSIONS $\ldots \ldots \ldots \ldots \ldots \ldots .6$

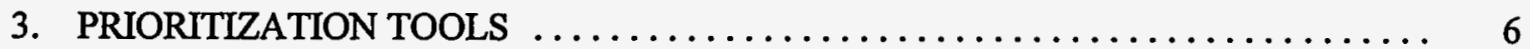

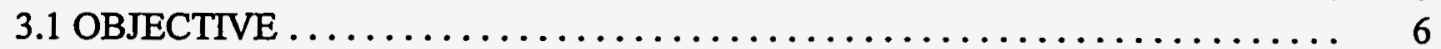

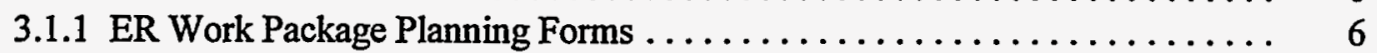

3.1.2 Environmental Restoration Benefit Assessment Matrix ............. 7

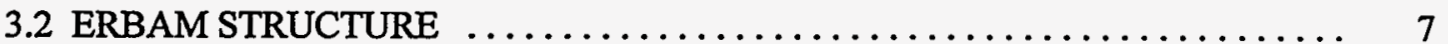

3.3 ERBAM SELECTION CRITERIA $\ldots \ldots \ldots \ldots \ldots \ldots \ldots \ldots \ldots \ldots \ldots \ldots \ldots, 11$

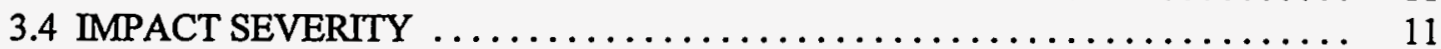

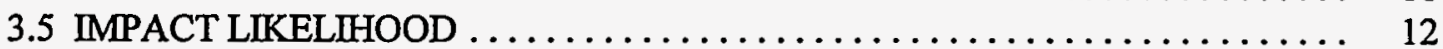

3.6 DERIVING THE WORK PACKAGE SCORES $\ldots \ldots \ldots \ldots \ldots \ldots \ldots \ldots \ldots \ldots$

3.7 APPLICATION RULES AND ASSUMPTIONS $\ldots \ldots \ldots \ldots \ldots \ldots \ldots \ldots \ldots \ldots \ldots$

Appendix A: ERBAM IMPACT CRITERIA DEFINITIONS $\ldots \ldots \ldots \ldots \ldots \ldots \ldots \ldots$

Appendix B: ERBAM IMPACT ASSESSMENT DEVELOPMENT ........... 27 



\section{FIGURES}

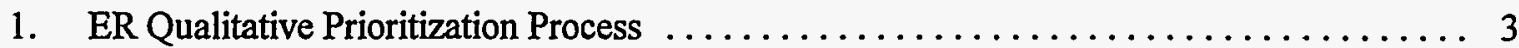

2. ER Work Package Planning Form $\ldots \ldots \ldots \ldots \ldots \ldots \ldots \ldots \ldots \ldots \ldots \ldots$

3. Environmental Restoration Benefit Assessment Matrix (ERBAM) $\ldots \ldots \ldots \ldots \ldots \ldots$

\section{TABLES}

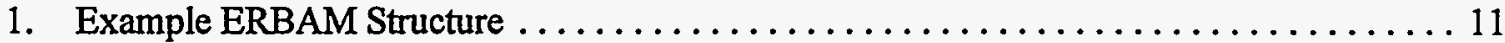

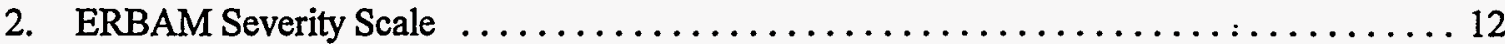

3. Event Likelihood Scale for Risk Impact Categories $\ldots \ldots \ldots \ldots \ldots \ldots \ldots \ldots \ldots \ldots$

4. Event Likelihood Scale for Socio-economic and Programmatic Impact Categories $\ldots \ldots 13$

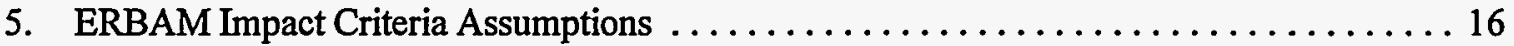




\section{ACRONYMS}

$\begin{array}{ll}\text { ADS } & \text { activity data sheet } \\ \text { CRM } & \text { Center for Risk Management } \\ \text { D\&D } & \text { Decontamination and Decommissioning } \\ \text { DOE } & \text { U.S. Department of Energy } \\ \text { EPA } & \text { U.S. Environmental Protection Agency } \\ \text { ER } & \text { Environmental Restoration } \\ \text { ERBAM } & \text { Environmental Restoration Benefit Assessment Matrix } \\ \text { FY } & \text { fiscal year } \\ \text { K-25 } & \text { Oak Ridge K-25 Site } \\ \text { MCIS } & \text { Management Control Information System } \\ \text { LMES } & \text { Lockheed Martin Energy Systems } \\ \text { ORO } & \text { Oak Ridge Operations } \\ \text { ORNL } & \text { Oak Ridge National Laboratory } \\ \text { ORR } & \text { Oak Ridge Reservation } \\ \text { PGDP } & \text { Paducah Gaseous Diffusion Plant } \\ \text { PORTS } & \text { Portsmouth Gaseous Diffusion Plant } \\ \text { S\&M } & \text { Surveillance and Maintenance } \\ \text { Y-12 } & \text { Oak Ridge Y-12 Plant }\end{array}$




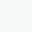




\section{EXECUTIVE SUMMARY}

The risk-based prioritization methodology presented in this document is used to identify Environmental Restoration (ER) Program activities that reduce the most significant risks or provide the most value toward achieving the ER mission at U.S. Department of Energy, Oak Ridge Field Office (DOE-ORO) sites. Prioritization is conducted as an integral component of the fiscal funding cycle to establish program budget priorities. The methodology provides the ER Program with a framework for 1) organizing information about identified DOE-ORO environmental problems, 2) generating qualitative assessments of the long- and short-term risks posed by DOE-ORO environmental problems, and 3) evaluating the benefits associated with candidate work packages to reduce those risks. This document presents the technical basis for the decision support tools and prioritization process.

The identification, evaluation, and prioritization of ER fiscal funding decisions is conducted qualitatively and relies on the technical expertise and professional judgment of Lockheed Martin Energy Systems, Inc. (LMES) and DOE ER program/project experts, managers, and regulatory agency representatives. The ER Prioritization Board, composed of senior DOE and LMES ER program managers and representatives from the U.S. Environmental Protection Agency (EPA) (Region IV), Tennessee Department of Environment and Conservation, Kentucky Department of Environmental Protection, and Ohio Environmental Protection Agency, conducts the final "scoring" and prioritization of work packages.

Two decision aids facilitate the decision-making process. The ER Work Package Planning Form is completed by site technical experts and project managers for each candidate work package and submitted to the ER Prioritization Board for use in evaluating and prioritizing the work packages. The Environmental Restoration Benefit Assessment Matrix (ERBAM) is a three-dimensional analytical decision support tool containing 1) a standard set of impact categories (i.e., selection criteria) that balance the major objectives within the ER Program, 2) a scale for measuring impact severity, and 3) a scale for measuring impact likelihood. To derive a score representing the benefits of a work package, each criterion's weight is multiplied by a value representing the severity of an impact and a value representing the likelihood of an impact. The matrix evaluation yields a numerical value that describes the existing situation at a site and a value that describes the situation that would exist after a work package has been implemented. The delta $(\Delta)$ risk score represents the benefits a work package provides. This score is used initially to rank a set of work packages. 


\section{INTRODUCTION}

\subsection{PURPOSE}

This document presents the risk-based prioritization methodology developed to evaluate and rank Environmental Restoration (ER) work packages at the five U. S. Department of Energy, Oak Ridge Field Office (DOE-ORO) sites [i.e., Oak Ridge K-25 Site (K-25), Portsmouth Gaseous Diffusion Plant (PORTS), Paducah Gaseous Diffusion Plant (PGDP), Oak Ridge National Laboratory (ORNL), and the Oak Ridge Y-12 Plant (Y-12)], the ER Off-site Program, and Central ER. This prioritization methodology was developed to support the increased rigor and formality of work planning in the overall conduct of operations within the DOE-ORO ER Program. Prioritization is conducted as an integral component of the fiscal ER funding cycle to establish program budget priorities.

The purpose of the ER risk-based prioritization methodology is to provide ER management with the tools and processes needed to evaluate, compare, prioritize, and justify fiscal budget decisions for a diverse set of remedial action, decontamination and decommissioning, and waste management activities. The methodology provides the ER Program with a framework for 1) organizing information about identified DOE-ORO environmental problems, 2) generating qualitative assessments of the long- and short-term risks posed by DOE-ORO environmental problems, and 3) evaluating the benefits associated with candidate work packages designed to reduce those risks. Prioritization is conducted to rank ER work packages on the basis of the overall value (e.g., risk reduction, stakeholder confidence) each package provides to the ER Program. Application of the methodology yields individual work package "scores" and rankings that are used to develop fiscal budget requests. This document presents the technical basis for the decision support tools and prioritization process.

\subsection{OBJECTIVE}

The ultimate objective of prioritization is to evaluate and prioritize ER activities that reduce the most significant risks or provide the most value toward achieving the ER mission, thereby focusing energy and resources on the actions that provide the greatest return on ER investments.

\subsection{STRATEGY}

The large number of areas and buildings on the Oak Ridge Reservation (ORR) and the finite resources available to address these areas has necessitated the development of a method to prioritize the areas and buildings and response actions based on risk reduction. The ER risk-based prioritization methodology is applied on an annual basis to support the development of ER budget requests. Budget requests are developed through a qualitative, multi phased risk management process by Lockheed Martin Energy Systems, Inc. (LMES) and DOE ER program managers using input from site-level ER program/project managers, technical experts, and representatives from the appropriate federal and state regulatory agencies. Results derived from application of the prioritization method do not dictate final budget decisions but provide managers with a basis from which fiscal resources can be judiciously allocated. 


\subsubsection{Approach}

The identification, evaluation, and prioritization of ER fiscal funding decisions is conducted qualitatively and relies on the technical expertise and management/professional judgment of LMES and DOE ER program/project experts, managers, and regulatory agency representatives rather than on probabilistic risk analyses or detailed mathematical analyses. Managers and technical experts apply an analytical decision support tool to consistently and equitably evaluate and compare ER work packages to derive a defensibly ranked set of fiscal funding decisions (Fig. 1).

To reduce the degree of bias inherent in a qualitative process, an objective decision-making body, the ER Prioritization Board, has been assembled and is responsible for conducting final "scoring" and prioritization of work packages. The ER Prioritization Board is composed of senior DOE and LMES ER program managers, along with representatives from the U.S. Environmental Protection Agency (EPA) (Region IV), Tennessee Department of Environment and Conservation, Kentucky Department of Environmental Protection, and Ohio Environmental Protection Agency; only the ER Prioritization Board scores the work packages and determines the final prioritization of work activities. To develop the risk-based work package priorities, the board uses information and subjective risk/benefit appraisals supplied by site-level ER program/project managers, risk assessment experts, and technical experts.

\subsubsection{Prioritization Tools}

Two decision aids were developed to facilitate the decision-making process: 1) a work package planning and data gathering mechanism and 2) an analytical decision support tool.

The ER Work Package Planning Form provides a consistent format for gathering information about candidate work packages. The form is completed by site technical experts and project managers and is submitted to the ER Prioritization Board for use in evaluating and prioritizing the work packages.

The Environmental Restoration Benefit Assessment Matrix (ERBAM) is an analytical decision support tool which was developed to balance all relevant decision parameters within the dynamic and multifaceted ER Program. Because an ER work package can be viewed as an effort to reduce either the severity or the likelihood of an negative impact resulting from accidental release of radioactive or chemical pollutants, the ERBAM is a three-dimensional tool containing: 1) a standard set of impact categories (i.e., selection criteria), 2) a scale for measuring impact severity, and 3) a scale for measuring impact likelihood. ER management, working with federal and state regulators, agreed on impact criteria which balance the major objectives within the ER program: protection of public health, protection of the environment, protection of on-site workers, consideration of stakeholder/community preference, achievement of the ER mission, and optimization of costefficiency. Each criterion's weight is multiplied by a value representing the severity of an impact and a value representing the likelihood of an impact. The matrix evaluation yields a numerical value that describes the existing situation at a site and a value that describes the situation that would exist after a work package has been implemented. The delta $(\Delta)$ risk score represents the benefits a work package provides. This score is used initially to rank a set of work packages. 


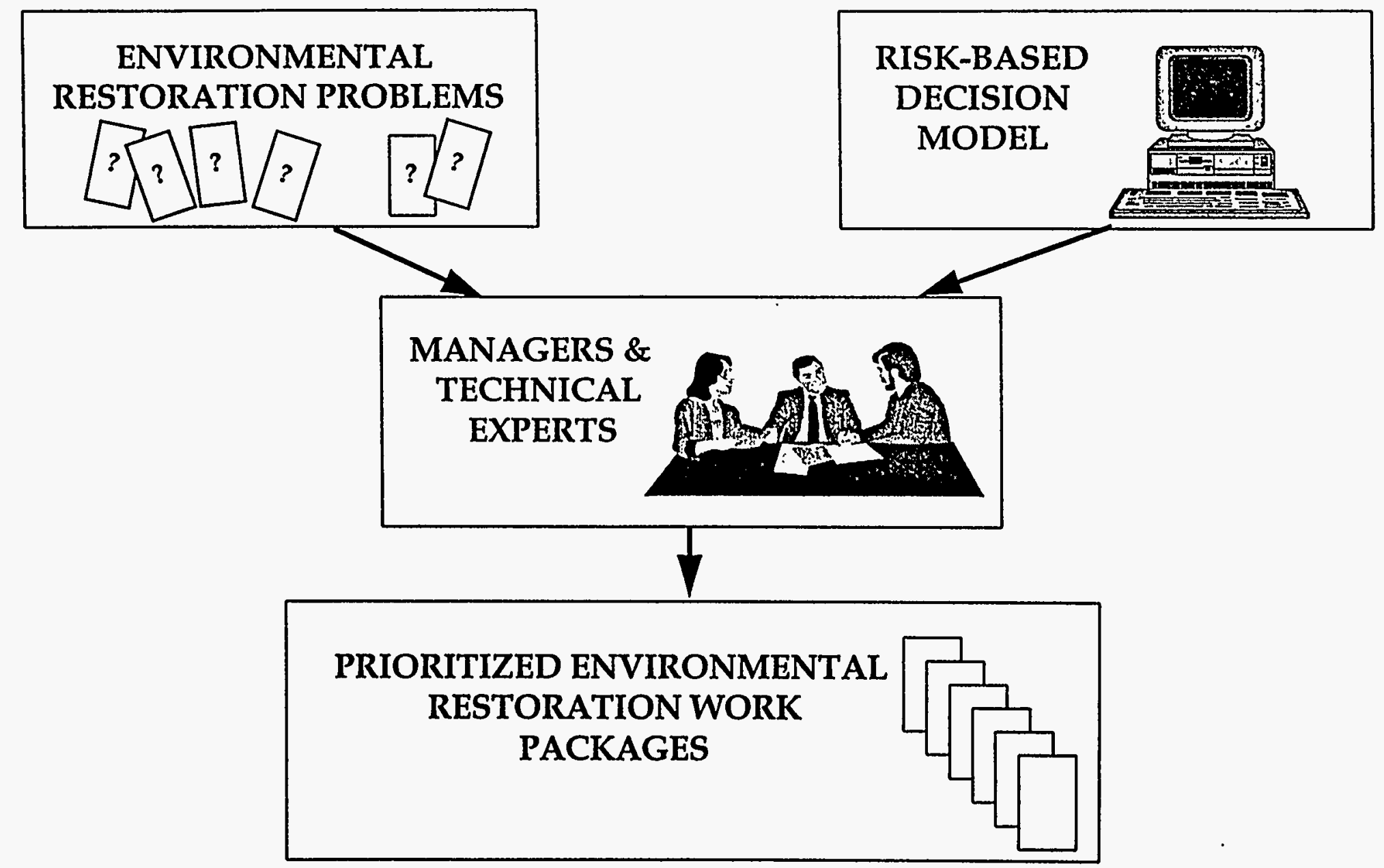

Fig. 1. ER qualitative prioritization process. . 
The ERBAM was modeled after the Integrated Resource Management System matrix, which has been used historically by DOE and LMES to rank compliance and operational activities. Multi-attribute utility analysis provided the basis for ERBAM development and application. Chapter 3 presents a detailed description of the ERBAM decision support tool and its application.

\section{PROCESS APPLICATION}

\subsection{PROCESS APPLICATION STEPS}

Implementation of the ER risk-based prioritization methodology is a systematic process that involves four distinct steps: 1) identification of candidate work packages to be prioritized, 2) evaluation of candidate work packages, 3) comparative analysis of candidate work packages and development of the risk-based Priority List, and 4) development of resource requests based on the Priority List.

\subsubsection{Identification of Candidate Work Packages}

Development and assemblage of work packages and activity descriptions to be scored by the ER Prioritization Board is achieved through collaboration of site-level ER program/project managers, LMES Central ER managers, technical experts, and representatives from federal and state regulatory agencies using baseline planning information. Descriptions of each activity are developed, and work is "packaged" in appropriate activity groups.

\subsubsection{Evaluation of Candidate Work Packages}

Using technical work package data gathered and documented by site-level ER program/project managers and technical experts, the ER Prioritization Board meets to evaluate each work package with respect to the standard set of ERBAM decision criteria.

\subsubsection{Development of the Risk-based Priority List}

The results of the work package evaluations are computed, and a relative risk-based ranking of all work packages is generated. The ER Prioritization Board and representatives from the appropriate federal and state regulatory agencies review the relative results and finalize the Priority List.

\subsubsection{Development of Fiscal Resource Requests}

Once the board has approved the Priority List, the results are applied on an annual basis to support the development of ER budget requests. Fiscal resource requests are determined by reviewing the Priority List and current budget information to develop two additional lists: 1) the Baseline Activity List and 2) the Funding Profile.

First, the Baseline Activity List is developed by applying current ER baseline cost information to the Priority List generated from the risk-based ranking. Using the Baseline Activity List as a basis, Activity Data Sheets (ADSs) and other budget request documents are developed. Second, the Funding Profile for a specific fiscal year is produced by applying fiscal year specific budget information to the Baseline Activity List. The Funding Profile allocates dollars to activities based on the rankings in the Priority List (from highest to lowest priority) and the funding constraints received 
in DOE ER budget guidance. This exercise produces a "funding line." Therefore, it is the allocation of dollars to work packages in the development of the Funding Profile that determines ER funding decisions.

\subsection{ROLES AND RESPONSIBILITIES}

Prioritization requires the participation of 1) site-level ER program/project managers and technical experts, 2) representatives from the ORNL Center for Risk Management (CRM), 3) ER Business Operations, 4) upper-level LMES and DOE ER program managers, and 5) representatives from the appropriate federal and state regulatory agencies. The following text describes the roles and responsibilities of all participants.

\subsubsection{Site-level ER Program/Project Managers and Technical Experts}

Site-level ER program and project managers and technical experts participate in the development of the list of work activities to be considered for evaluation and prioritization. Project managers are responsible for completing a Work Package Planning Form for each activity to be considered. The Work Package Planning Forms are submitted to the manager of the Management Control Information System (MCIS) and forwarded to the LMES ER Technical Integration Manager.

\subsubsection{ORNL Center for Risk Management}

Members of the ORNL CRM Risk Assessment Council assist project managers in compiling information specific to the risk categories on ERBAM in preparation for completing the Work Package Planning Forms; the forms are completed prior to the prioritization sessions. The ORNL CRM prioritization administrator receives and reviews the Work Package Planning Forms for entry into the MCIS database prioritization files and is responsible for maintaining the integrity of project prioritization data and scoring results.

\subsubsection{ER Business Operations}

ER Business Operation Program personnel provide financial management information regarding activities to be prioritized. The Business Operations MCIS manager, using information from the Work Package Planning Forms, coordinates project identification and data for the prioritization and funding processes. After each scoring session, Business Operations personnel apply the current, approved ER baseline cost information to the final Priority List to establish the Target Case and other required cases for DOE ER budget planning exercises. Business Operations is also responsible for the development of fiscal year (FY) Funding Profiles through the allocation of current FY budget dollars.

\subsubsection{Upper-level LMES and DOE ER Managers}

The ER Prioritization Board is responsible for evaluating and prioritizing all candidate work packages. The board consists of seven senior DOE and LMES ER managers:

- Director, DOE-ORO ER Division

- Deputy Director, LMES ER Division

- Chief, DOE-ORO Oak Ridge Remediation Branch

- Chief, DOE-ORO Program Integration Branch

- Chief, PGDP Environmental Program and Compliance Branch 
- Director, LMES ER Division

- Director, LMES ER Division

- Site Manager, ERWM, PORTS

\subsubsection{Representatives from Appropriate Federal and State Regulatory Agencies}

Representatives from EPA (Region IV and Region V) and Tennessee, Ohio, and Kentucky state regulatory agencies participate in the ER Prioritization Board sessions and provide input on the resulting risk-based Priority List.

\subsection{CONDUCT OF ER PRIORITIZATION BOARD SESSIONS}

The ER Prioritization Board sessions are formalized to increase the level of objectivity in the decision-making process. An ER Prioritization Board session will be conducted only if all Board members are present. The LMES ER Technical Integration Manager, working with a team of representatives from ORNL CRM, serves as facilitator of board sessions and assists the board members in prioritization activities. The results of the ERBAM application are assembled into a risk-based priority ranking that the board reviews to ensure consistency and compatibility with on-going activities or newly-identified priorities and objectives. The board may use its management prerogative to adjust the risk-based rankings; however, ranking adjustments must be documented and included in the prioritization methodology's output. The board has final approval authority of the scores and the resulting Priority List.

\section{PRIORITIZATION TOOLS}

\subsection{OBJECTIVE}

The primary challenge associated with using a risk management approach to prioritize a diverse range of candidate ER work packages is to develop appropriate decision support tools that will facilitate a consistent, equitable evaluation and comparative analysis. Determining relevant decision attributes and their relative importance in a dynamic, multifaceted program must be handled carefully if decisions are to be made on a "level playing field." The tools developed for use in prioritization include the 1) ER Work Package Planning Form, a work package planning and data gathering mechanism, and 2) ERBAM, a decision framework for evaluating and prioritizing work packages.

The purpose of these decision aids is to provide management with a formalized approach to developing fiscal funding requests based on the degree of risk reduction and value of other benefits provided. The tools provide a structured approach for measuring the overall importance or value of work packages. Application of these tools generates a risk-based ranking of work packages that can be used to develop and justify fiscal funding decisions.

\subsubsection{ER Work Package Planning Form}

The Work Package Planning Form is a project level work package planning mechanism structured to gather the necessary information to conduct an equitable and consistent comparison of diverse work packages using the ERBAM. Information captured on the form feeds directly into the application of the ERBAM. 
Each form requires documentation of 1) work package identification data (i.e., work package title, work package manager, facility, ADS identifier), 2) work package descriptive data (i.e., scope, objectives, contaminants of concern, degree of contamination, location of source, specific regulatory drivers/issues, and significant milestones and schedule issues), 3) work package risk/benefit appraisal (i.e., brief descriptions of the risks associated with not implementing a work package and the benefits associated with implementing a work package), and 4) recommended ERBAM work package scores (Fig. 2).

The form is completed by project level ER program and project managers and technical experts who, by virtue of their direct experience with defining and implementing site-specific remediation activities, are qualified to gather, document, and submit work package data and develop suggested work package assessments. These data (Fig. 2) are applied by the ER Prioritization Board in evaluating the work packages during prioritization sessions and should provide sufficient, substantive, and detailed information to support the board in making informed scoring decisions for each criterion.

\subsubsection{Environmental Restoration Benefit Assessment Matrix}

The ERBAM is a management decision-aiding tool designed to provide a framework for conducting a consistent, equitable comparison and ranking of candidate ER work packages. The matrix is periodically reviewed and revised to reflect the changing needs of the multifaceted ER Program. Work packages are evaluated relative to a standard set of weighted decision criteria that represent ER's most critical issues and concerns. Application of the ERBAM yields individual numerical scores for identified candidate ER work packages and ranks them by their relative importance. The relative importance of a work package is expressed in terms of the level of risk reduction it provides in a range of considerations (decision criteria) related to ER's strategic objectives. The criteria are public health, environmental protection, site personnel safety, stakeholder preference, mission, and cost-effectiveness (Fig. 3).

\subsection{ERBAM STRUCTURE}

The structure of the ERBAM is based on multi-attribute analysis principles to address and balance a wide range of issues (i.e., development of a hierarchy of objectives) and produce accurate results (i.e., development of scales for measuring and estimating work package performance).

First, establishment of priorities within the ER Program requires balancing a wide range of issues relevant to the organization's mission, goals, and strategic objectives. Therefore, the decision tool designed for ER contains impacts in six broad areas. Impacts are weighted to reflect their relative importance to the DOE-ORO ER mission. Second, ER work packages are designed to reduce either the severity or the probability of an undesirable consequence resulting from existing environmental problems. Therefore, the decision tool is a three-dimensional matrix containing 1) a range of impact areas, 2) a scale for measuring the severity of a negative impact, and 3) a scale for measuring the event likelihood. Third, to establish the relative importance of ER work packages, ER must evaluate the existing situation at its sites and then must evaluate the degree to which an ER work package will reduce those risks. Therefore, the decision tool is designed to measure the delta $(\Delta)$ work package risk score for the severity and likelihood of existing risks before work package implementation and the severity and likelihood of residual risks after work package implementation. 
I. ER Work Package Identification Section

1. Work Package Fiscal Year:

2. Facility:
- ER Central
- ER Off-site
- K-25 Site
- Paducah Plant
ㅁ Portsmouth Plant
- X-10/ORNL
口 Y-12 Plant

3. Work Package Title:

4. ADS Identifier:

5. Project Manager/Phone:

II. ER Work Package Description Section (Attach Additional Pages As Necessary)

6. Provide a General Description of ER Work Package (include work package scope \& objective, known contaminants and location of source, and other applicable descriptive data):

7. List Specific Regulatory Issues/Drivers (if applicable)

8. List Significant Milestones or Scheduled Accomplishments:

\section{ER Work Package Appraisal Section}

Describe the Risks/Impact of Not Implementing or Continuing This Work Package, and Then Describe the Benefits of Continuing or Implementing This Work Package, In the Following Categories:

9. Public Health:

Fig. 2. ER Work Package Planning Form. 


\section{ER Work Package Appraisal Section (cont.)}

10. Environmental Protection:

11. Site Personnel Safety:

12. Stakeholder Preference:

\section{Mission:}

14. Cost -effectiveness:

\section{ER Work Package Scoring Section}

Enter the Cell Coordinates below:

At Most, One Before-Score and One After-Score Per Category

\begin{tabular}{|l|l|l|l|l|l|l||}
\hline & $\begin{array}{c}\text { Public } \\
\text { Health }\end{array}$ & $\begin{array}{c}\text { Environmental } \\
\text { Protection }\end{array}$ & $\begin{array}{c}\text { Site } \\
\text { Personnel } \\
\text { Safety }\end{array}$ & $\begin{array}{c}\text { Stakeholder } \\
\text { Preference }\end{array}$ & Mission & $\begin{array}{c}\text { Cost- } \\
\text { effectiveness }\end{array}$ \\
\hline Before: & & & & & & \\
\hline & & & & & & \\
\hline After:
\end{tabular}

Fig. 2. (continued). 


\begin{tabular}{|c|c|c|c|c|}
\hline ERBAM & \multicolumn{4}{|c|}{ EVENT LIKELHHOOD } \\
\hline & $\mathbf{A}$ & B & $\mathbf{C}$ & D \\
\hline IMPACTS & $\begin{array}{l}\text { Very } \\
\text { High }\end{array}$ & High & Medium & Low \\
\hline $\begin{array}{l}\text { Public Health } \\
\text { 1. Significanthigh risk of exposure to off-site public } \\
\text { 2. Moderate risk of exposure to off-site public } \\
\text { 3. Low risk of exposure to off-site public }\end{array}$ & $\begin{array}{l}3000 \\
1500 \\
750 \\
\end{array}$ & $\begin{array}{l}1500 \\
750 \\
375 \\
\end{array}$ & $\begin{array}{l}750 \\
375 \\
187.5 \\
\end{array}$ & $\begin{array}{l}0 \\
0 \\
0 \\
\end{array}$ \\
\hline $\begin{array}{l}\text { Environmental Protection } \\
\text { 4. Widespread and/or long-term directly or indirectly induced damage to } \\
\text { ecological systems } \\
\text { 5. Widespread and/or short-term or localized and long-term directly or } \\
\text { indirectly induced damage to ecological systems } \\
6 \text {. Localized and/or short-term directly or indirectly induced damage to } \\
\text { ecological systems }\end{array}$ & $\begin{array}{l}2000 \\
1000 \\
500\end{array}$ & $\begin{array}{l}1000 \\
500 \\
250\end{array}$ & $\begin{array}{l}500 \\
250 \\
125\end{array}$ & $\begin{array}{l}0 \\
0 \\
0\end{array}$ \\
\hline $\begin{array}{l}\text { Site Personnel Safety } \\
\text { 7. Significant/high risk to on-site personnel of physical injury requiring } \\
\text { hospitalization with significant lost-time or exposure greater than } \\
\text { occupational limits. } \\
\text { 8. Moderate risk to on-site personnel of physical injury requiring medical } \\
\text { treatment or exposure of } 20-100 \% \text { of occupational limits. } \\
\text { 9. Low risk to on-site personnel of physical injury requiring first aid or } \\
\text { exposure of less than } 20 \% \text { of occupational limits or reportable, removable } \\
\text { skin contamination. }\end{array}$ & $\begin{array}{l}2000 \\
1000 \\
500\end{array}$ & $\begin{array}{l}1000 \\
500 \\
250\end{array}$ & $\begin{array}{l}500 \\
250 \\
125\end{array}$ & $\begin{array}{l}0 \\
0 \\
0\end{array}$ \\
\hline $\begin{array}{l}\text { Stakeholder Preference } \\
\text { 10. Significant stakeholder interest } \\
\text { 11. Moderate stakeholder interest } \\
\text { 12. Minor stakeholder interest } \\
\end{array}$ & $\begin{array}{l}1000 \\
500 \\
250 \\
\end{array}$ & $\begin{array}{l}500 \\
250 \\
125 \\
\end{array}$ & $\begin{array}{l}250 \\
125 \\
62.5 \\
\end{array}$ & $\begin{array}{l}0 \\
0 \\
0 \\
\end{array}$ \\
\hline $\begin{array}{l}\text { Mission } \\
\text { 13. Significant impact on cost, schedule or environmental impact of } \\
\text { multiple activities resulting in shutdown of key program components } \\
\text { 14. Moderate impact on cost, schedule or environmental impact of more } \\
\text { than two activities } \\
\text { 15. Minor impact on cost, schedule or environmental impact of one other } \\
\text { activity }\end{array}$ & $\begin{array}{r}500 \\
250 \\
\end{array}$ & $\begin{array}{r}250 \\
125 \\
\end{array}$ & $\begin{array}{l}125 \\
62.5 \\
\end{array}$ & $\begin{array}{l}0 \\
0 \\
\end{array}$ \\
\hline $\begin{array}{l}\text { Cost-Effectiveness } \\
16 . \text { Loss of opportunity to avoid total future costs } \$ 5-25 \mathrm{M} \text {, or annual costs } \\
\$ 1-5 \mathrm{M} \\
17 \text {. Loss of opportunity to avoid total future costs } \$ 1-5 \mathrm{M} \text {, or annual cost } \\
\text { \$0.2-1M } \\
\text { 18. Loss of opportunity to avoid total future costs }<\$ 1 \mathrm{M} \text {, or annual cost }< \\
\text { \$0.2M }\end{array}$ & $\begin{array}{l}1000 \\
500 \\
250\end{array}$ & $\begin{array}{l}500 \\
250 \\
125\end{array}$ & $\begin{array}{l}250 \\
125 \\
62.5\end{array}$ & $\begin{array}{l}0 \\
0 \\
0\end{array}$ \\
\hline
\end{tabular}

Fig. 3. Environmental Restoration Benefit Assessment Matrix (ERBAM). 
The prioritization methodology uses a matrix which represents the severity of potential consequences, or impacts, by rows and the event likelihood by columns (Table 1).

Table 1. Example ERBAM structure

\begin{tabular}{|c|c|c|c|c|}
\hline CRITERIA & \multicolumn{4}{|c|}{ EVENT LIKELIHOOD } \\
\hline IMPACT & Very High & High & Medium & Low \\
\hline $\begin{array}{c}\text { High } \\
\text { Severity Level }\end{array}$ & - & & & \\
\hline $\begin{array}{c}\text { Moderate } \\
\text { Severity Level }\end{array}$ & & & & \\
\hline $\begin{array}{c}\text { Low } \\
\text { Severity Level }\end{array}$ & & & & \\
\hline
\end{tabular}

\subsection{ERBAM SELECTION CRITERIA}

The first component of the three-dimensional ERBAM consists of the six criteria represented by the larger, inclusive rows in the matrix. The criteria have been assigned weights or measures of relative importance by the ER Prioritization Board. Brief descriptions of the six selection criteria are provided in the following list. More detailed definitions of the ERBAM impact criteria are provided in Appendix A.

- Public health addresses potential adverse impacts on the health and safety of the surrounding or affected off-site community.

- Environmental protection addresses potential adverse impacts on the environment, including physical degradation of surrounding or affected ecological systems and/or their constituents.

- Site personnel safety addresses potential adverse impacts on the health and safety of site personnel working inside the site boundary, including physical injury and exposure to radioactive or chemical pollutants.

- Stakeholder preference addresses potential adverse impacts on the level of confidence that the public maintains in the DOE-ER Program.

- Mission addresses potential adverse impacts on ER's ability to accomplish the DOE-ORO mission.

- Cost-effectiveness addresses potential adverse impacts on ER's ability to avoid future costs.

\subsection{IMPACT SEVERITY}

The second component of the ERBAM, represented by the severity scale in the matrix, is a measurement of the magnitude of an impact. Determining the severity of a potential impact is the first step toward determining the priority of an environmental problem. The six risk impact criteria 
included in the ERBAM have associated levels of severity (graded as significant/high, moderate, and low) which have been assigned numerical weights. Further details about the severity levels within each parameter are provided in Appendix A.

The numerical weights of the scores reflect the relationship between the six criteria. Weight assignments are based on the cost of the consequence, the impact on health and safety, and unwillingness to accept the risk. The impact severity scale (Table 2) has been developed on the premise that reduction of an impact from high to moderate is of greater overall significance than reduction of an impact from moderate to low.

Table 2. ERBAM severity scale

\begin{tabular}{|l|c|c|c|}
\hline \multirow{2}{*}{ CRITERIA } & \multicolumn{3}{|c|}{ SEVERITY } \\
\cline { 2 - 4 } & SIGNIFICANT/HIGH & MODERATE & LOW \\
\hline Public Health & 3000 & 2000 & 1000 \\
\hline $\begin{array}{l}\text { Environmental } \\
\text { Protection }\end{array}$ & 2000 & 1000 & 500 \\
\hline $\begin{array}{l}\text { Site Personnel } \\
\text { Safety }\end{array}$ & 2000 & 1000 & 500 \\
\hline $\begin{array}{l}\text { Stakeholder } \\
\text { Preference }\end{array}$ & 1000 & 500 & 250 \\
\hline Mission & 1000 & 500 & 250 \\
\hline Cost-effectiveness & 1000 & 500 & 250 \\
\hline
\end{tabular}

\subsection{EVENT LIKELIHOOD}

The third component of the three-dimensional ERBAM is the event likelihood scale. Reducing the likelihood of a negative consequence is as important as reducing its severity; therefore, the matrix includes an event likelihood scale containing four levels (i.e., very high, high, medium and low). As with determining the severity of impacts, the collective experience and judgment of management must be employed to determine the likelihood of an event occurrence for each criterion deemed applicable to a work package. A difference exists in interpretation of risk impact categories and socio-economic and programmatic impact categories in the ERBAM event likelihood scale. For risk to public health, environmental protection, and site personnel safety, the event likelihood scale considers the possibility of occurrence very high if it is likely to occur within one year. A high possibility of occurrence is likely within a 2- to 10-year time frame, a medium possibility of occurrence is likely within an 11- to 100-year time frame, and a low possibility is one which is not likely to occur within 100 years (Table 3 ).

As with the impact severity scale, the event likelihood scale is based on the premise that reduction of a very likely risk of an occurrence to a moderately likely risk (e.g., reducing the likelihood of an event occurring from a one chance in 1 year to a one chance in 10 years level) is more significant than reduction of a moderately likely risk to a low likely risk. 
Table 3. Event likelihood scale for risk impact categories

\begin{tabular}{|c|c|c|c|c|}
\hline LIKELIHOOD & VERY HIGH & HIGH & MEDIUM & LOW \\
\hline $\begin{array}{c}\text { PERCENTAGE } \\
\text { RISK } \\
\text { REDUCTION }\end{array}$ & $100 \%$ & $50 \%$ & $25 \%$ & $0 \%$ \\
\hline TIME FRAME & $<1 \mathrm{yr}$. & $1-10 \mathrm{yrs}$. & $10-100 \mathrm{yrs}$. & $>100 \mathrm{yrs}$ \\
\hline
\end{tabular}

Stakeholder preference, mission, and cost-effectiveness measure socio-economic and programmatic impacts; therefore, time frames per likelihood of occurrence of these impacts are significantly shorter than the time frames for the environmental and safety and health impact criteria. For these socio-economic and programmatic impacts, a 5-year (rather than a 100-year) time frame is used for likelihood of occurrence (Table 4).

Table 4. Event likelihood scale for socio-economic and programmatic impact categories

\begin{tabular}{|c|c|c|c|c|}
\hline LIKELIHOOD & VERY HIGH & HIGH & MEDIUM & LOW \\
\hline $\begin{array}{c}\text { PERCENTAGE } \\
\text { RISK } \\
\text { REDUCTION }\end{array}$ & $100 \%$ & $50 \%$ & $25 \%$ & $0 \%$ \\
\hline TIME FRAME & $<1 \mathrm{yr}$ & $1-3 \mathrm{yrs}$ & $3-5 \mathrm{yrs}$ & $>5 \mathrm{yrs}$ \\
\hline
\end{tabular}

\subsection{DERIVING THE WORK PACKAGE SCORES}

Each cell on the matrix has a risk value equal to the product of its respective impact criterion weight multiplied by a measure of severity and a measure of likelihood as follows:

$$
\text { Risk Value }=W_{i} x S_{i} x L_{i},
$$

where

$$
\begin{aligned}
& W_{i}=\text { weight of impact category, } \\
& S_{i}=\text { severity of the impact, } \\
& L_{t}=\text { likelihood of occurrence. }
\end{aligned}
$$

Several qualitative assessments are generated to derive a score for a work package. An assessment is first made to determine potential risks posed by existing identified environmental 
problems. This assessment serves the prioritization exercise as the before score, indicating the situation prior to work package implementation:

$$
\text { Risk }_{\text {(before) }}=W_{i} \times S_{t b} \times L_{i b},
$$

where

$W_{i}=$ weight of impact category,

$S_{i b}=$ severity of the impact before work package implementation,

$L_{t b}=$ likelihood of impact occurrence before work package implementation.

In a comparative risk-based prioritization of environmental restoration activities, the objective is to determine the risk that a work package reduces or eliminates or the benefits associated with implementing a corrective action (e.g., the utility of a work package). The benefits of a work package are measured by the degree to which the package reduces existing risk or improves quality or productivity. Therefore, the next step is to determine the severity and probability of risk remaining after an action has been implemented. The level of severity or the probability (or both) of an unwanted consequence should be lower after a work package has been implemented. Addressed in this way, the end result will reflect the benefits of a work package as the risk reduction or opportunity resulting from implementation:

$$
\operatorname{Risk}_{\text {(affer) }}=W, x S_{i a} x L_{i a}
$$

where

$W_{i}=$ weight of impact category,

$S_{i a}=$ severity/weight of the impact after work package implementation,

$L_{i a}=$ likelihood of impact occurrence after work package implementation.

The delta $(\Delta)$ scores for each applicable impact category are calculated in the following manner:

$$
\Delta \text { Risk }=\left(W_{i} \times S_{i b} x L_{i b}\right)-\left(W_{i} \times S_{i a} \times L_{i a}\right)
$$

Scores are determined in this manner for all six impact categories. Summation of these values yields a net benefit score for each work package; the score reflects the level of risk reduction and other benefits achieved by implementing the work package. Using this common sense approach, the amount of anticipated risk reduction is determined by matching a work package's beneficial characteristics with the parameters in the ERBAM, thereby yielding a numerical value that can be used to initially rank all work packages or issues competing for the same limited resources.

Further details regarding specific considerations applied in before/after project implementation assessment development are provided in Appendix B.

\subsection{APPLICATION RULES AND ASSUMPTIONS}

General prioritization process assumptions and specific ERBAM impact criteria assumptions 
facilitate consistent application of the ERBAM. General process assumptions developed prior to and during the prioritization exercise are:

- Allocation of funding will not be considered during the ERBAM analyses.

- When determining work package after scores, assume the "life of the work package" rather than one-year risk reduction or incremental risk reduction.

- When determining work package after scores, assume work package effectiveness/success in terms of scope and objective.

- To justify a "Very High" probability of occurrence, the impact must be either an existing condition or must be anticipated to occur within 1 year/12 months from the FY under evaluation.

- The prioritization of ER work packages using the ERBAM is a comparative analysis. Therefore, during each application of the ERBAM, for each impact criterion, the board will establish benchmark work packages that define the highest achievable severity level in a given application.

Specific assumptions have been developed to facilitate common interpretation of the ERBAM impact criteria (Table 5). 
Table 5. ERBAM impact criteria assumptions

\begin{tabular}{|c|c|}
\hline \multicolumn{2}{|r|}{ ERBAM IMPACT CRITERIA ASSUMPTIONS } \\
\hline Public Health & $\begin{array}{l}\text { - For RA, assume that applicable administrative controls/boundary } \\
\text { controls are in place for exposure scenarios } \\
\text { - For decontamination and decommissioning (D\&D) projects, assume } \\
\text { realistic and consistent probability of failure for release scenarios (e.g., do } \\
\text { not assume that surveillance and maintenance (S\&M) completely reduces } \\
\text { the risk of release and subsequent exposure) }\end{array}$ \\
\hline Environmental Protection & $\begin{array}{l}\text { - Assume polychlorinated biphenls will always have a moderate impact } \\
\text { - On-site ecosystems are afforded the same protection as off-site } \\
\text { ecosystems }\end{array}$ \\
\hline Site Personnel Safety & $\begin{array}{l}\text { - This category covers on-site risks of exposure and physical injury to all } \\
\text { LMES/DOE staff, subcontractors, and on-site visitors } \\
\text { - For RA, assume that applicable administrative controls or boundary } \\
\text { controls are in place when developing exposure scenarios } \\
\text { - For D\&D, assume realistic and consistent probability of failure when } \\
\text { developing release scenarios (e.g., do not assume that S\&M completely } \\
\text { reduces the risk of release and subsequent exposure) } \\
\text { - Assume reasonable work-arounds for workers who receive their annual } \\
\text { exposure limits (e.g., workers will be assigned to different work areas) }\end{array}$ \\
\hline Stakeholder Preference & $\begin{array}{l}\text { - "Stakeholders" include the surrounding, affected, or interested/concerned } \\
\text { public, interest groups, and Site-specific Advisory Boards }\end{array}$ \\
\hline Mission & $\begin{array}{l}\text { - Refers to ER mission } \\
\text { - Consider dependency among work packages when determining impact } \\
\text { on mission (e.g., a highly ranked project may depend on a support project } \\
\text { thereby raising the score of the support project) } \\
\text { - Default score is NA; therefore, the risk scores are the drivers }\end{array}$ \\
\hline Cost-effectiveness & $\begin{array}{l}\text { - Address cost avoidance estimates associated with implementing work } \\
\text { packages } \\
\text { - Consider dependency among work packages when determining impacts } \\
\text { on productivity and cost avoidance } \\
\text { - Consider restart costs } \\
\text { - Default score is NA; therefore, the risk scores are the drivers } \\
\text { - Default score for new starts is NA }\end{array}$ \\
\hline
\end{tabular}


Appendix A

ERBAM IMPACT CRITERIA DEFINITIONS 



\section{A. ERBAM IMPACT CRITERIA DEFINITIONS}

This appendix provides detailed definitions of the ERBAM decision parameters and distinguishing factors for use in interpreting the ERBAM severity scale.

\section{A.1 PUBLIC HEALTH CRITERIA}

Exhibit A.1. Public health criteria

\begin{tabular}{|c|c|c|c|c|}
\hline ERBAM & \multicolumn{4}{|c|}{ EVENT LIKELIHOOD } \\
\hline \multirow[b]{2}{*}{ IMPACTS } & $\mathbf{A}$ & B & C & D \\
\hline & $\begin{array}{l}\text { Very } \\
\text { High }\end{array}$ & High & Medium & Low \\
\hline Public Health & & & & \\
\hline 1. Significant/high risk of exposure to off-site public & 3000 & 1500 & 750 & 0 \\
\hline 2. Moderate risk of exposure to off-site public & 1500 & 750 & 375 & 0 \\
\hline 3. Low risk of exposure to off-site public & 750 & 375 & 187.5 & 0 \\
\hline
\end{tabular}

Public Health Impact Definition: The three criteria address potential adverse impacts on the health and safety of the surrounding or affected human population (offsite). Public health is used to assess potential impacts to off-site communities from accidents involving the release of radioactive or hazardous materials. Under current conditions (i.e., large buffer zones, distances of receptors from the site, opportunities for contaminant degradation, dilution, and natural reduction of concentrations), no exposures resulting in fatalities are expected. If such a situation should exist, it would receive the highest score. Some suggested guidelines for use of quantitative information are listed in the following discussion. Without quantitative information, relative judgments must be made based on available data.

Public Health Severity Level 1: Significant/high risk of exposure to off-site public means that a condition may result in exposing the off-site community to radioactive or hazardous materials in excess of published, acceptable limits defined in 10 CFR 20 (radioactive materials) and 40 CFR 264 (hazardous materials). However, such exposure is not expected to result in a loss of life or permanent disability from immediate injuries or from cancer or genetic damage that could be directly linked to the condition. Choosing this severity level means that serious injuries could be sustained by an offsite population. Impact is considered widespread and long-term. Where quantitative information is available, a risk $\geq 10^{-3}$, a hazard index $>1$, or other comparable risk assessment information indicate Severity Level 1.

Public Health Severity Level 2: Moderate risk of exposure to off-site public means that a condition may result in exposing the off-site community to radioactive or hazardous materials at or near published, acceptable limits defined in 10 CFR 20 (radioactive materials) and 40 CFR 264 (hazardous materials). Such exposure is not expected to result in a loss of life, permanent disability, or serious injury, and the incidence of latent effects such as cancer or leukemia would probably not be selectively observable among other causes (i.e., natural, background radiation). Choosing this severity level means that moderate injuries could be sustained by an off-site population or individual. 
Impact can be widespread or localized but is short-term. Where quantitative information is available, a risk $=10^{-5}-10^{-3}$ or hazard index $>1$, or other comparable risk assessment information indicate Severity Level 2.

Public Health Severity Level 3: Low risk of exposure to off-site public means that a condition may result in exposing the off-site community to radioactive or hazardous materials below published, acceptable limits defined in 10 CFR 20 (radioactive materials) and 40 CFR 264 (hazardous materials). Such exposure is not expected to result in a loss of life, permanent disability, or serious or moderate injury, and again, the incidence of latent effects such as cancer or leukemia would probably not be selectively observable among other causes (i.e., natural, background radiation). Choosing this severity level means that minor injuries could be sustained by an off-site population or individual. Impact is localized and short-term. Where quantitative information is available, a risk $\leq 10^{-5}$ or hazard index $<1$, or other comparable risk assessment information indicate Severity Level 3.

\section{A.2 ENVIRONMENTAL PROTECTION CRITERIA}

Exhibit A.2. Environmental protection criteria

\begin{tabular}{|l|c|c|c|c|}
\hline \multicolumn{1}{|c|}{ ERBAM } & \multicolumn{4}{|c|}{ EVENT LIKELIHOOD } \\
\hline \multicolumn{1}{|c|}{ IMPACTS } & A & B & C & D \\
\cline { 2 - 5 } & $\begin{array}{l}\text { Very } \\
\text { High }\end{array}$ & High & Medium & Low \\
\hline $\begin{array}{l}\text { Environmental Protection } \\
\text { 4. Widespread and/or long-term directly or indirectly induced } \\
\text { damage to ecological systems }\end{array}$ & 2000 & 1000 & 500 & 0 \\
$\begin{array}{l}\text { 5. Widespread and/or short-term or localized and long-term } \\
\text { directly or indirectly induced damage to ecological systems } \\
\text { 6. Localized and/or short-term directly or indirectly induced } \\
\text { damage to ecological systems }\end{array}$ & 1000 & 500 & 250 & 0 \\
\hline
\end{tabular}

Environmental Protection Impact Definition: The criteria address potential adverse impacts on the environment, including physical degradation of surrounding or affected ecological systems and harmful effects on plants and animals. Environmental protection is used to assess potential widespread, localized, and long- and short-term impacts on entire ecological systems or constituents. These systems or elements could be impacted directly or indirectly as a result of damage to their habitat. The criteria are also used to assess impacts resulting in loss of use of natural resources such as land or water for a specified amount of time depending on the severity level. Impacts result from accidents involving the release or spill of radioactive or hazardous materials.

Environmental Protection Severity Level 4: Widespread and/or long-term directly or indirectly induced damage to ecological systems means that a condition may result in serious and extensive environmental insult that is either sufficiently widespread or of a magnitude to destroy or profoundly imperil entire ecological subsystems or constituents or incur any injury to threatened and endangered species or any loss of wetlands. Such damage is expected to result in a long-term loss of use, but the use is expected to be restored. Choosing this severity level means that serious damage could be sustained by an ecosystem. 
Environmental Protection Severity Level 5: Widespread and/or short-term or localized and longterm directly or indirectly induced damage to ecological systems means that a condition may result in an environmental insult that is not as widespread or severe as that represented by Severity Level 4 but of a magnitude to damage entire ecological subsystems or constituents. Such damage is expected to result in temporary loss of use, but use is expected to be restored. Choosing this severity level means that moderate damage could be sustained by an ecosystem (at the community level).

Environmental Protection Severity Level 6: Localized and/or short-term directly or indirectly damage to ecological systems means that a condition may result in an environmental insult that is not as widespread or severe as that represented by Severity Level 5 but of a magnitude sufficient to damage biota in a given region. However, such damage is not expected to result in a loss of use. Choosing this severity level means that low-level damage could be sustained by an ecosystem (at the species or population level).

\section{A.3 SITE PERSONNEL SAFETY CRITERIA}

Exhibit A.3. Site personnel safety criteria

\begin{tabular}{|l|c|c|c|c|}
\hline \multicolumn{1}{|c|}{ ERBAM } & \multicolumn{3}{|c|}{ EVENT LIKELIHOOD } \\
\hline \multicolumn{1}{|c|}{ IMPACTS } & A & B & C & D \\
\cline { 2 - 5 } & $\begin{array}{l}\text { Very } \\
\text { High }\end{array}$ & High & Medium & Low \\
\hline $\begin{array}{l}\text { Site Personnel Safety } \\
\text { 7. Significant/high risk to on-site personnel of physical injury } \\
\text { requiring hospitalization with significant lost-time or exposure } \\
\text { greater than occupational limits. }\end{array}$ & 2000 & 1000 & 500 & 0 \\
$\begin{array}{l}\text { 8. Moderate risk to on-site personnel of physical injury } \\
\text { requiring medical treatment or exposure of 20-100\% of } \\
\text { occupational limits. } \\
\text { 9. Low risk to on-site personnel of physical injury requiring first } \\
\text { aid or exposure of less than 20\% of occupational limits or } \\
\text { reportable, removable skin contamination. }\end{array}$ & 1000 & 500 & 250 & 0 \\
\hline
\end{tabular}

Site Personnel Safety Impact Definition: The criteria address potential adverse impacts on the health and safety of personnel inside the site boundary. Site personnel safety is used to assess potential impacts resulting from accidents involving the release or spill of radioactive or hazardous materials to on-site DOE and LMES personnel, DOE contractors and subcontractors, remediation workers, and site guests and visitors. The release would require a transport pathway so that one or more persons onsite could be exposed to contaminants at levels sufficient to result in the severity levels defined in the following discussion. In addition, for remediation workers, the criteria cover the potential for physical danger including injury(ies) incurred by conventional industrial accidents (e.g., catastrophic failure of equipment or components, personnel caught in rotating or moving machinery, roof/structural failure, personnel falling from high locations, and personnel exposed to hightemperature or high-pressure fluid releases).

Site Personnel Safety Severity Level 7: Significant/high risk of exposure or physical injury to onsite personnel requiring hospitalization with significant lost-time or exposure greater than 
occupational limits means that a condition may result in 1) exposure of on-site personnel to radioactive or hazardous materials in excess of published, acceptable occupational limits defined in DOE Orders 5480.11 (radioactive materials) and 5480.3 (hazardous materials) or 2) significant injury requiring a hospital stay longer than one day (i.e., admittance to the hospital beyond emergency room treatment) and significant lost time from work for recuperation.

Site Personnel Safety Severity Level 8: Moderate risk of exposure or physical injury to on-site personnel requiring medical treatment or exposure of 20-100\% of occupational limits means that a condition may result in 1) exposure of on-site personnel to radioactive or hazardous materials near (20-100\%) published, acceptable occupational limits defined in DOE Orders 5480.11 (radioactive materials) and 5480.3 (hazardous materials) or 2) moderate injury requiring only emergency room treatment, unless the injuries involve contaminated wounds. Recuperation is expected, and lost-time would not be extensive (one day). Lost time from exposures could be reduced through reassignment to jobs without exposure potential.

Site Personnel Safety Severity Level 9: Low risk of exposure or physical injury to on-site personnel requiring first aid or exposure of less than $20 \%$ of occupational limits or reportable, removable skin contamination means that a condition may result in 1) exposure of on-site personnel to radioactive or hazardous materials below published, acceptable occupational limits defined in DOE Orders 5480.11 (radioactive materials) and 5480.3 (hazardous materials) or 2) minor injury or personnel concern. An accident report or "occurrence report" would be filed, but no hospital treatment would be necessary and lost-time is not expected.

\section{A.4 STAKEHOLDER PREFERENCE CRITERIA}

Exhibit A.4. Stakeholder preference criteria

\begin{tabular}{|l|l|l|l|l|}
\hline \multirow{2}{*}{ ERBAM } & \multicolumn{4}{|c|}{ EVENT LIKELIHOOD } \\
\hline \multirow{2}{*}{ IMPACTS } & A & B & C & D \\
\cline { 2 - 5 } & Very High & High & Medium & Low \\
\hline Stakeholder Preference & & & & \\
10. Significant stakeholder interest & 1000 & 500 & 250 & 0 \\
11. Moderate stakeholder interest & 500 & 250 & 125 & 0 \\
12. Minor stakeholder interest & 250 & 125 & 62.5 & 0 \\
\hline
\end{tabular}

Stakeholder Preference Impact Definition: The criteria address the level of interest or concern that the public has expressed or is likely to express with regard to an identified environmental problem or ER action. An impact on stakeholder preference must indicate some degree of loss of public confidence in the DOE-ORO.

Stakeholder Preference Severity Level 10: Significant stakeholder interest means that a condition involves highly visible or highly community-sensitive matters or is politically controversial or otherwise (positively or negatively) distinct or visible and could result in legal challenges or external requests for further, in-depth investigations. This severity level is chosen if stakeholder interest or concern has been expressed or is likely to be expressed (e.g., more than one local public meeting has been held, and the condition has elicited media coverage at the national level). 
Stakeholder Preference Severity Level 11: Moderate stakeholder interest means that a condition involves mildly visible or mildly community-sensitive matters or is moderately polemic (politically) or otherwise (positively or negatively) distinct or visible. However, no legal challenges or external requests for further, in-depth investigations are expected. This severity level is chosen if stakeholder interest or concern has been expressed or is likely to be expressed (e.g., one local public meeting has been held, and the condition has elicited media coverage at the local level).

Stakeholder Preference Severity Level 12: Low stakeholder interest means that a condition does not involve significant visible or community-sensitive matters, politically sensitive issues, or otherwise (positively or negatively) distinct or visible aspects. No legal challenges or external requests for further, in-depth investigations are expected. This severity level is chosen if stakeholder interest or concern has been expressed or is likely to be expressed (i.e., one or more letters of concern or interest have been received, one or more verbal comments have been noted), but no media coverage is expected.

\section{A.5 MISSION CRITERIA}

Exhibit A.5. Mission criteria

\begin{tabular}{|c|c|c|c|c|}
\hline ERBAM & \multicolumn{4}{|c|}{ EVENT LIKELIHOOD } \\
\hline & $\mathbf{A}$ & B & $\mathbf{C}$ & $\mathbf{D}$ \\
\hline IMPACTS & $\begin{array}{l}\text { Very } \\
\text { High }\end{array}$ & High & Medium & Low \\
\hline $\begin{array}{l}\text { Mission } \\
\text { 13. Significant impact on cost, schedule or environmental } \\
\text { impact of multiple activities resulting in shutdown of key }\end{array}$ & 1000 & 500 & 250 & 0 \\
\hline $\begin{array}{l}\text { 14. Moderate impact on cost, schedule or environmental } \\
\text { impact on more than two activities }\end{array}$ & 500 & 250 & 125 & 0 \\
\hline $\begin{array}{l}\text { 15. Minor impact on cost, schedule or environmental } \\
\text { impact on one other activity }\end{array}$ & 250 & 125 & 62.5 & 0 \\
\hline
\end{tabular}

Mission Impact Definition: The criteria address conditions that would impede the ER Program's ability to accomplish the DOE-ORO mission which considers both direct and indirect impacts that may result from not implementing an activity. The criteria are designed to cover impacts such as temporary or permanent shutdown of an entire facility or program or a portion of a facility or program and other impediments. The criteria also address indirect impacts on mission that may result due to project dependencies. For example, failure to implement a support project may result in an inability to perform/implement a highly ranked project, thereby impacting the mission.

Mission Severity Level 13: Significant impact on the cost, schedule, or environmental impact of multiple activities resulting in shutdown of key program components means that not implementing the work package under evaluation would have a direct negative impact on multiple activities and thereby seriously impede the ER Program's ability to accomplish the DOE-ORO mission.

Mission Severity Level 14: Moderate impact on the cost, schedule, or environmental impact of more than two activities means that not implementing the work package under evaluation would 
have a direct negative impact on more than two activities and thereby would impede the ER Program's ability to accomplish the DOE-ORO mission.

Mission Severity Level 15: Minor impact on the cost, schedule, or environmental impact of one other activity means that not implementing the work package under evaluation would have a minor or insignificant impact on the ER Program's ability to accomplish the DOE-ORO mission.

\section{A.6 COST-EFFECTIVENESS CRITERIA}

Exhibit A.6. Cost-effectiveness criteria

\begin{tabular}{|c|c|c|c|c|}
\hline ERBAM & \multicolumn{4}{|c|}{ EVENT LIKELIHOOD } \\
\hline \multirow[b]{2}{*}{ IMPACTS } & $\mathbf{A}$ & B & C & D \\
\hline & Very High & High & Medium & Low \\
\hline Cost-effectiveness & & & & \\
\hline $\begin{array}{l}\text { 16. Loss of opportunity to avoid total future costs } \\
\$ 5-25 \mathrm{M} \text {, or annual costs } \$ 1-5 \mathrm{M}\end{array}$ & 1000 & 500 & 250 & 0 \\
\hline $\begin{array}{l}\text { 17. Loss of opportunity to avoid total future costs } \\
\$ 1-5 \mathrm{M} \text {, or annual cost } \$ 0.2-1 \mathrm{M}\end{array}$ & 500 & 250 & 125 & 0 \\
\hline $\begin{array}{l}\text { 18. Loss of opportunity to avoid total future costs }< \\
\$ 1 \mathrm{M} \text {, or annual cost }<\$ 0.2 \mathrm{M}\end{array}$ & 250 & 125 & 62.5 & 0 \\
\hline
\end{tabular}

Cost-effectiveness Impact Definition: The criteria address the potential for avoiding future costs or a condition that would result in additional or unnecessary future costs to the ER Program.

Cost-effectiveness Severity Level 16: Loss of opportunity to avoid future costs $\$ 5-25 M$ or annual costs $\$ 1-5 M$ means that not implementing the work package under evaluation would impede the opportunity to avoid future costs that total $\$ 5-25 \mathrm{M}$ or annual costs of $\$ 1-5 \mathrm{M}$.

Cost-effectiveness Severity Level 17: Loss of opportunity to avoid future costs $\$ 1-5 M$ or annual cost $\$ 0.2-1 M$ means that not implementing the work package under evaluation would impede the opportunity to avoid future costs that total $\$ 1-5 \mathrm{M}$ or annual costs of $\$ .2-1 \mathrm{M}$.

Cost-effectiveness Severity Level 18: Loss of opportunity to avoid future costs $<\$ 1 M$ or annual cost $<\$ 0.2 M$ means that not implementing the work package under evaluation would impede the opportunity to avoid future costs that total $\angle \$ 1 \mathrm{M}$ or annual cost $\angle \$ 0.2 \mathrm{M}$. 
Appendix B

\section{ERBAM IMPACT ASSESSMENT DEVELOPMENT}





\section{B. ERBAM IMPACT ASSESSMENT DEVELOPMENT}

This appendix provides specific instructions for developing qualitative assessments to derive work package scores. The following text provides detailed assessment development instructions and considerations that should be applied in developing assessments for each of the six ERBAM impact criteria.

\section{B.1 PUBLIC HEALTH ASSESSMENTS}

To develop an assessment of the potential impacts on public health, the ER Prioritization Board qualitatively evaluates the risk of exposure (in terms of magnitude and likelihood) to the off-site public resulting from an accidental release of radioactive or chemical pollutants. Therefore, the board derives a scenario that describes a reasonable "worst-case" consequence that would result if the action (or set of actions) under evaluation is not taken. Using this scenario, the board determines the event likelihood and agree upon a before implementation score. Using the same scenario, the board then determines the degree of risk reduction afforded by an action in terms of both magnitude and event likelihood and agree upon an after implementation score.

Specific considerations applied in generating qualitative assessments regarding protection of public health include:

- contaminant(s) of concern,

- environmental media (e.g., groundwater, surface water, soil, air),

- exposure pathway(s) (e.g., dermal, ingestion, inhalation),

- source (s) location,

- nearest public water supply location,

- potential for contaminant migration,

- potential off-site human receptors (e.g., sensitivity and proximity of population), and transportation risks.

\section{B.2 ENVIRONMENTAL PROTECTION ASSESSMENTS}

To develop an assessment of the potential impacts on the environment, the ER Prioritization Board qualitatively evaluates the impacts (in terms of magnitude and likelihood) of accidental release of radioactive or chemical pollutants to an ecosystem and its constituents.. Therefore, the board derives a scenario that describes a reasonable "worst-case" consequence that would result if the action (or set of actions) under evaluation is not taken. Using this scenario, the board determines the event likelihood and agrees upon a before implementation score. Using the same scenario, the board then determines the degree of impact reduction afforded by an action in terms of both magnitude and event likelihood and agrees upon an after implementation score.

Specific considerations applied in generating qualitative assessments regarding protection of the environment include:

- contaminant(s) of concern,

- ecosystem structure, dynamics, function, environmental media (e.g., groundwater, surface water, soil, air), 
- exposure pathway(s) (e.g., dermal, ingestion, inhalation),

- impacts on future use,

- nearest water supply location,

- source(s) location,

- nature, magnitude, and extent of effects,

- potential cascading impacts (e.g., food web),

- potential for contaminant migration,

- potential receptors (i.e., threatened and endangered species or otherwise sensitive species or ecosystems), and

- transportation risks.

\section{B.3 SITE PERSONNEL SAFETY ASSESSMENTS}

To develop an assessment of the potential impacts on site personnel safety, the ER Prioritization Board qualitatively evaluates the impact (in terms of magnitude and likelihood) of accidental release of radioactive or chemical pollutants on all on-site personnel. Therefore, the board derives a scenario that describes a reasonable "worst-case" consequence that would result if the action (or set of actions) under evaluation is not taken. Using this scenario, the board determines the event likelihood and agrees upon a before implementation score. Using the same scenario, the board then determines the degree of impact reduction afforded by an action in terms of both magnitude and event likelihood and agrees upon an after implementation score.

Specific considerations applied in generating qualitative assessments regarding protection of onsite personnel include:

- contaminant(s) of concern,

- environmental media (e.g., groundwater, surface water, soil, air),

- equipment failure, structural failure/collapse and other physical risks,

- exposure pathway(s),

- source(s) location,

- potential for contaminant migration,

- potential on-site human receptors (e.g., remediation workers, office workers), and

- transportation risks.

\section{B.4 STAKEHOLDER PREFERENCE ASSESSMEINTS}

To develop an assessment of the existing level of stakeholder interest or concern regarding a site or activities at a site, the ER Prioritization Board includes the public, the customer (i.e., DOE), and LMES personnel as "stakeholders" and uses management judgment to measure expressed or anticipated interest or concern from these parties. The board bases assessments on several factors, including 1) whether the stakeholders are aware of the problem/issues/activities at a site, 2) whether a relatively significant degree of interest or concern has been communicated, and 3 ) whether the work package under evaluation is of particular importance or otherwise of interest to DOE and site personnel. The board derives a scenario that describes a reasonable "worst-case" consequence that would result if the action (or set of actions) under evaluation is not taken. Using this scenario, the board determines the event likelihood and agrees upon a before implementation score. For the stakeholder preference criterion, an after implementation score will generally be negligible $(0$ or $*)$ because implementing an action is assumed to eliminate further stakeholder interest or concern. 
Specific considerations applied in generating qualitative assessments regarding stakeholder preference include:

- letters and comments,

- public meetings,

- publicity (media coverage),

- $\quad$ site/public historical relations, and

- stakeholder awareness.

\section{B.5 MISSION ASSESSMENTS}

To develop an assessment of potential impacts on the ability to accomplish the DOE-ORO mission, the ER Prioritization Board qualitatively evaluates all cascading or synergistic impacts (in terms of magnitude and likelihood) to LMES and DOE that may result if a work package is not implemented. Therefore, the board derives a scenario that describes a reasonable "worst-case" consequence that would result if the action (or set of actions) under evaluation is not taken. Using this scenario, the board determines the event likelihood and agrees upon a before implementation score. Using the same scenario, the board then determines the degree of impact reduction afforded by an action in terms of both magnitude and event likelihood, and agrees upon an after implementation score.

Specific considerations that must be applied in generating qualitative assessments regarding mission include:

- dependency among work packages,

- loss of employee morale and increased employee stress,

- loss of Award Fee, and

- potential for temporary or permanent facility/site shutdown.

\section{B.6 COST-EFFECTIVENESS ASSESSMENTS}

To develop an assessment of potential impacts on ER's opportunity to avoid future costs, the ER Prioritization Board qualitatively evaluates all cascading or synergistic impacts (in terms of magnitude and likelihood) to LMES and DOE that may result if a work package is not implemented. Therefore, the board derives a scenario that describes a reasonable "worst-case" consequence that would result if the action (or set of actions) under evaluation is not taken. Using this scenario, the board determines the event likelihood and agrees upon a before implementation score. Using the same scenario, the board then determines the degree of impact reduction afforded by an action in terms of both magnitude and event likelihood and agrees upon an after implementation score.

Specific considerations that must be applied in generating qualitative assessments regarding cost-effectiveness include:

- increased costs to implement mandated upgrades,

- impacts to restart costs, and

- potential loss of LMES stock value or commercial business roles. 


\section{DISTRIBUTION}

1. R. O. Barnett, Jr.

2. R. R. Bonczek

3. H. L. Boston

4. J. T. Bradbury

5. K. W. Cook

6. D. G. Cope

7. T. L. Dahl, Sr.

8. J. L. Dail

9. M. F. P. Delozier

10. S. Garland

11. P. L. Goddard

12. K. M. Golden

13. P. A. Gourieux

14. C. S. Haase

15. L. D. Hyde

16. B. L. Kimmel, II

17. J.R. Lyons, II

18. J.C. Massey

20. J. Morgan

21. J. H. Moyer

22. B. D. Nourse

23. L. D. Owens

24. T. S. Purucker

25. B. Ramsey

26. D. M. Steinhauff

27. G. W. Suter II

28. C. C. Travis

29. T. D. Taylor

30. R. K. White

31. Central Research Library

32-35. ER Central Document Management Center

36. V.F. Boston, DOE Oak Ridge Operations Office, P. O. Box, Oak Ridge, TN 37831-8541

37. R. E. Edwards, DOE Paducah Operations Office, 5600 Hobbs Road, West Paducah, KY 42086

38. W. N. Lingle, DOE Oak Ridge Operations Office, P.O. Box 2001, Oak Ridge, TN 378318541

39. Office of Assistant Manager for Energy Research and Development, DOE Oak Ridge Field Office, P.O. Box 2001, Oak Ridge, TN 37831-8600

40. Office of Scientific and Technical Information, P.O. Box 62, Oak Ridge, TN 37831

41-43. T.C. Perry, DOE Oak Ridge Opertions Office , P.O.Box, 2001, Oak Ridge, TN 37831-8541

44. S.P. Riddle, DOE Oak Ridge Opertions Office, P.O.Box, 2001, Oak Ridge, TN 378318541

45. J.D. Sheppard, DOE Portsmouth Operations Office, 3930 US Route 23, Parameter Road, Piketon, $\mathrm{OH} 45661$

46. R.C. Sleeman, DOE Oak Ridge Opertions Office, P.O.Box, 2001, Oak Ridge, TN 378318541 